\title{
PENGIDENTIFIKASIAN KEMAMPUAN INTERPERSONAL MAHASISWA MELALUI MODEL PEMBELAJARAN PELATIHAN KESADARAN (AWARENES TRAINING)
}

\author{
${ }^{1)}$ Mekar Ismayani, ${ }^{2)}$ Yeni Rostikawati, ${ }^{3)}$ Alfa Mitri Suhara \\ ${ }^{1)}$ mekarismayani@ rocketmail.com
}

${ }^{1,2,3)}$ STKIP SILIWANGI BANDUNG

\begin{abstract}
ABSTRAK
Dalam penelitian ini, peneliti khusus menyoroti kemampuan afektif yang harus dikuasai oleh peserta didik dengan menumbuhkan kemampuan interpersonal seperti yang sudah dipaparkan sebelumnya. Alasan kuat peneliti memilih aspek afektif, berangkat dari sebuah permasalahan yang teridentifikasi dari lapangan, bahwa kemampuan interpersonal mahasiswa masih sangat rendah, khususnya di kalangan mahasiswa STKIP Siliwangi yang menjadi objek penelitian. Salah satu faktor yang menjadi acuan adalah dalam hal tanggung jawab terhadap tugas-tugas perkuliahan yang tidak pernah lepas dari masalah plagiarisme. Oleh karena itu, tujuan penelitian ini adalah untuk: 1) Mendeskripsikan tanggung jawab mahasiswa dalam menyelesaikan tugas yang diberikan oleh dosen; 2) Mendeskripsikan pemahaman diri mahasiswa terhadap tugas yang diberikan dosen; 3) Mendeskripsikan kesadaran perilaku diri sendiri (mahasiswa) dan kesadaran terhadap orang lain ketika melakukan interaksi sosial. Berdasar pada paparan permasalahan tersebut, maka peneliti mengangkat sebuah model pembelajaran Pelatihan Kesadaran (Awarenes Training). Uno (2012, hlm. 20) menjelaskan bahwa model ini dikembangkan oleh Milliam Schutz. Penekanan dalam model ini adalah pelatihan interpersonal sebagai sarana peningkatan kesadaran pribadi (pemahaman diri individu). Tujuan model ini adalah untuk meningkatkan pemahaman diri dan kesadaran akan perilaku diri sendiri dan orang lain sehingga dapat membantu siswa mengembangkan perkembangan pribadi dan sosialnya. Penelitian ini merupakan penelitian yang akan terus dikembangkan ke depannya hingga menghasilkan sebuah produk yaitu berupa instrumen evaluasi proses. Penekanan evaluasi proses ini ada pada aspek afektif sehingga menjadi instrumen evaluasi berbasis karakter. Dalam penelitian ini, objek yang diamati adalah orang yaitu sampel mahasiswa Program Studi Pendidikan Bahasa dan Sastra Indonesia di STKIP Siliwangi Bandung pada semua angkatan. Pengamatan dilakukan saat berlangsung proses pembelajaran di kelas serta hasil jawaban angket yang diisi oleh mahasiswa. Butir-butir soal angket yang diberikan pada mahasiswa merujuk pada indikator kemampuan interpersonal berdasarkan teori yang ada dalam model pembelajaran Pelatihan Kesadaran (Awarenes Training). Data hasil angket diperkuat dengan hasil pengamatan selama proses pembelajaran yang dilakukan oleh dosen dengan tetap beracuan pada indikator yang sama dengan angket. Pengujian keabsahan data dilakukan dengan meningkatkan ketekunan, triangulasi, menggunakan bahan referensi, dan mengadakan member check. Oleh karena itu, jika dilihat dari proses pengamatan dalam menggumpulkan data, metode penelitian ini menggunakan kualitatif.
\end{abstract}

Kata Kunci: kemampuan interpersonal, pelatihan kesadaran (awareness training)

\begin{abstract}
In this study, researchers specifically highlight affective abilities that must be mastered by the learner to cultivate interpersonal skills, as already described previously. A strong reason the researchers chose the affective aspects, departing from an identified problems of the field, that the interpersonal skills the students are still very low, especially among students STKIP Siliwangi which is the object of research. One factor is that the reference in terms of responsibility for the tasks of lectures that never escape from the problem of plagiarism. Therefore, the purpose of this study was to: 1) Describe the responsibility of the student in completing the tasks assigned by the lecturers; 2) Describe the student's self-understanding of the tasks assigned faculty; 3) Describe the behavior of self-awareness (students) and awareness of others when social interaction. Based on the exposure to these problems, the researchers raised a learning model Awareness Training (Awareness Training). Uno (2012, p. 20) explains that this model developed by Milliam Schutz. The emphasis in this model is the interpersonal training as a means of increasing personal awareness (understanding the individual). The purpose of this model is to increase self-understanding and awareness of one's own behavior and other people that can help students develop personal and social development. This research is to be further developed in the future to produce a product in the form of process evaluation instruments. The emphasis there is on the evaluation of this process so that it becomes an instrument of affective aspects of character-based evaluation. In this study, the observed object is a
\end{abstract}


person that is samples of students of Indonesian Language and Literature Education in STKIP Siliwangi Bandung on all forces. Observations were made during a learning process in the classroom as well as the results of the answers to a questionnaire completed by the students. Those items questionnaire given to students interpersonal skills refer to the indicators based on the theory that exist in the model lesson Awareness Training (Awareness Training). Data from the questionnaire were confirmed by observations during the learning process conducted by lecturers with fixed refers to the same indicators as the questionnaire. Testing the validity of the data is done by increasing diligence, triangulation, using reference materials, and conduct check. Therefore, when seen from the observation process used data, using qualitative research methods.

Keywords: interpersonal skills, training awareness (awareness training)

\section{PENDAHULUAN}

Proses pembelajaran merupakan suatu kegiatan yang di dalamnya terjadi interaksi antara pengajar dan peserta didik. Interaksi tersebut merupakan cara untuk menyampaikan materi ajar dari pengajar kepada peserta didik. Oleh karena itu, menurut Uno (2012, hlm. 2) bahwa dalam proses pembelajaran perlu adanya strategi yang efektif untuk memudahkan peserta didik menerima dan memahami materi pembelajaran. Pada akhirnya, tujuan pembelajaran dapat dikuasai dengan baik oleh peserta didik.

Sudah dipaparkan di atas, bahwa dalam proses pembelajaran akan terjadi "interaksi" antara peserta didik dengan pengajar maupun antara peserta didik dengan peserta didik. Dalam proses interaksi tersebut, kemampuan interpersonal peserta didik maupun pengajar memiliki peranan penting. Jika beracuan pada teori Gardner mengenai 8 keterampilan yang dimiliki oleh manusia, maka salah satunya yaitu keterampilan interpersonal. Kemampuan interpersonal menurut Gardner (dalam Santrock, 2009, hlm. 158) merupakan kemampuan untuk memahami dan secara efektif berinteraksi dengan orang lain. Keterampilan berinteraksi ini erat kaitannya dengan kemampuan afektif seseorang.

Dalam sebuah pembelajaran, Bloom menegaskan bahwa ada tiga aspek pembelajaran yang harus menjadi perhatian pengajar, yaitu aspek kognitif, afektif, dan psikomotor. Dalam penelitian ini, peneliti khusus menyoroti kemampuan afektif yang harus dikuasai oleh peserta didik dengan menumbuhkan kemampuan interpersonal seperti yang sudah dipaparkan sebelumnya. Alasan kuat peneliti memilih aspek afektif, berangkat dari sebuah permasalahan yang teridentifikasi dari lapangan, bahwa kemampuan interpersonal mahasiswa masih sangat rendah, khususnya di kalangan mahasiswa STKIP Siliwangi yang menjadi objek penelitian. Salah satu faktor yang menjadi acuan adalah dalam hal tanggung jawab terhadap tugas-tugas perkuliahan yang tidak pernah lepas dari masalah plagiarisme. Fakta tersebut didapatkan dari hasil penelitian terdahulu yang sudah dilakukan oleh Sahmini \& Rostikawati (2015) yang berjudul Pengembangan Evaluasi Keterampilan Menulis Karya Ilmiah dengan Pendekatan Sistem. Selain itu, Fluerentin dalam jurnalnya menyebutkan bahwa di lapangan dijumpai beberapa fenomena yang mengindikasikan bahwa generasi penerus atau anak didik tidak berkarakter. Pengalaman belajar di sekolah yang jelas didesign untuk pengembangan aspek kognitif, afektif, dan psikomotorik kurang "menyentuh" diri anak didik. Fluerentin mengaitkan hal tersebut dengan pembelajaran sikap dan lebih spesifik lagi dimulai dari hal yang sederhana tetapi sulit dilakukan, yaitu memiliki kesadaran (awareness) yang baik. Ia pun menjelaskan bahwa pembelajaran sikap yang dimaksud adalah pengalaman belajar yang berkenaan dengan bidang sikap, yang mencakup latihan kesadaran diri (self awareness), pemahaman multikultural, dan penguasaan kecakapan hidup (life skills). Pembelajaran sikap sarat dengan kesadaran akan nilai-nilai yang berlaku pada diri dan lingkungan (Fluerentin, 2012). dalam artikel jurnal lain seperti yang ditulis oleh Marlina (2014), ditemukan masalah mengenai tingkat keberhasilan belajar siswa yang rendah sehingga Marlina mencoba mengujicobakan model Pelatihan Kesadaran. Hasil penelitian menunjukkan bahwa penerapan model tersebut efektif menanamkan kesadaran belajar pada siswa sehingga hasil belajarnya meningkat.

Berdasarkan pada paparan permasalahan tersebut, maka peneliti mengangkat sebuah model pembelajaran Pelatihan Kesadaran (Awarenes Training). Uno (2012, hlm. 20) menjelaskan bahwa model ini dikembangkan oleh Milliam Schutz. Penekanan dalam model ini adalah pelatihan interpersonal sebagai sarana peningkatan kesadaran pribadi (pemahaman diri individu). 
Tujuan model ini adalah untuk meningkatkan pemahaman diri dan kesadaran akan perilaku diri sendiri dan orang lain sehingga dapat membantu siswa mengembangkan perkembangan pribadi dan sosialnya. Teori ini menjelaskan metode untuk meningkatkan kesadaran hubungan antarmanusia yang didasarkan atas keterbukaan, kejujuran, kesadaran diri, tanggung jawab, perhatian terhadap diri sendiri atau orang lain, dan orientasi pada kondisi saat ini. Model pembelajaran ini terdiri atas dua tahapan. Pertama adalah penyampaian dan penyelesaian tugas. Pada tahapan ini guru memberikan pengarahan tentang tugas yang akan diberikan dan bagaimana melaksanakannya. Tahapan kedua adalah diskusi atau analisis atau analisis tahap pertama.

Berdasarkan latar belakang tersebut, ada beberapa tujuan yang ingin dicapai melalui penelitian ini yaitu: 1) Mendeskripsikan tanggung jawab mahasiswa dalam menyelesaikan tugas yang diberikan oleh dosen; 2) Mendeskripsikan pemahaman diri mahasiswa terhadap tugas yang diberikan dosen; dan 3) Mendeskripsikan kesadaran perilaku diri sendiri (mahasiswa) dan kesadaran terhadap orang lain ketika melakukan interaksi sosial.

\section{LANDASAN TEORI}

\section{A. Teori Humanistik}

Teori belajar humanistik ini menekankan peranan lingkungan dan faktor-faktor kognitif dalam proses pelajar-mengajar. Teori belajar ini berusaha memahami perilaku belajar dari sudut pandang pelakunya, bukan dari sudut pandang pengamatnya. Tujuan utama para pendidik adalah membantu peserta didik untuk mengembangkan dirinya, yaitu membantu masing-masing individu untuk mengenal diri mereka sendiri sebagai manusia yang unik dan membantu dalam mewujudkan potensi-potensi yang ada dalam diri mereka. Teori humanistik ini memiliki pengaruh pada ilmu pendidikan dan penerapannya. Dalam Djiwandono (2009, hlm. 181) dijelaskan bahwa ahli-ahli teori humanistik menunjukkan: 1) tingkah laku individu pada mulanya ditentukan oleh bagaimana mereka merasakan dirinya sendiri dan dunia sekitarnya, dan 2) individu bukanlah satusatunya hasil dari lingkungan mereka seperti yang dikatakan oleh ahli teori tingkah laku, melainkan langsung dari dalam (internal), bebas memilih, dimotivasi oleh keinginan untuk aktualisasi diri (self-actualization) atau memenuhi potensi keunikan mereka sebagai manusia.
Teori humanistik ini dicetuskan oleh tiga orang tokoh, diantaranya yaitu Arthur Combs, Abraham H. Maslow, dan Carl R. Rogers. Berikut sedikit dibahas mengenai pandangan ketiga tokoh tersebut agar lebih mendalami prinsip-prinsip psikologi humanistik dan bagaimana menerapkannya dalam proses belajar.

Tokoh humanistik adalah Abraham Maslow (dalam Djiwandono, 2009, 182 - 183), R. Rogers, C. Buhler dan Arthur Comb. Menurut teori ini, guru harus berupaya menciptakan kondisi kelas yang kondusif, agar peserta didik merasa bebas dalam belajar mengembangkan diri baik emosional maupun intelektual. Teori humanistik timbul sebagai cara untuk memanusiakan manusia. Pada teori humanistik ini, pendidik seharusnya berperan sebagai pendorong bukan menahan sensivitas peserta didik terhadap perasaanya. Implikasi teori ini dalam pendidikan adalah sebagai berikut.

1) Bertingkah laku dan belajar adalah hasil pengamatan.

2) Tingkah laku yang ada dapat dilaksanakan sekarang (learning to do).

3) Semua individu memiliki dorongan dasar terhadap aktualisasi diri.

4) Sebagian besar tingkah laku individu adalah hasil dari konsepsinya sendiri.

5) Mengajar adalah bukan hal penting, tapi belajar bagi peserta didik adalah sangat penting.

6) Mengajar adalah membantu individu untuk mengembangkan suatu hubungan yang produktif dengan lingkungannya dan memandang dirinya sebagai pribadi yang cakap.

Dalam Djiwandono (2009, hlm. 348) dipaparkan bahwa Implikasi teori humanistik terhadap pengajaran adalah hubungan antara deficiency needs dan growth needs. Di sekolah, deficiency needs yang paling penting adalah kebutuhan siswa untuk dicintai dan dihargai. Jika siswa merasa tidak dicintai dan dihargai, dan dianggap tidak mampu, mereka tidak mempunyai motivasi kuat untuk mencapai growth needs. Selain itu, teori Maslow juga menawarkan implikasi-implikasi tertentu untuk mencapai kebutuhan tingkat yang lebih tinggi. Seorang siswa yang sukses dalam menguasai pengetahuan tertentu atau dapat menciptakan objek yang indah mungkin akan bertambah motivasinya dan bahkan berusaha mencapai tujuan yang lebih tinggi (Atkinson \& Raynor dalam Djiwandono, 2009, hlm. 349). Oleh karena itu, teori humanis ini bertujuan membentuk seorang individu paripurna sehingga dapat mencapai kebutuhan-kebutuhannya sebagai seorang individu dan makhluk sosial. 
Ada beberapa model pembelajaran yang termasuk pendekatan ini, diantaranya adalah pengajaran tidak langsung, pelatihan kesadaran, sinektik, sistem konseptual, dan pertemuan kelas. Dalam pembahasan ini hanya tiga model yang akan diperkenalkan, yaitu (1) model pembelajaran pengajaran tidak langsung (non-directivet eaching), (2) model pembelajaran pelatihan kesadaran (awareness training), dan (3) model pembelajaran pertemuan kelas (classroom meeting).

\section{B. Model Pembelajaran Pelatihan Kesadaran (Awarenes Training)}

Model pembelajaran pelatihan kesadaran merupakan suatu model pembelajaran yang ditujukan untuk meningkatkan kesadaran manusia. Model ini dikembangkan oleh Milliam Schutz. Ia menekankan pentingnya pelatihan interpersonal sebagai sarana peningkatan kesadaran pribadi (pemahaman diri individu). Ia percaya bahwa ada empat tipe perkembangan yang dibutuhkan untuk merealisasikan potensi individu secara utuh, yaitu (1) fungsi tubuh, (2) fungsi personal, termasuk didalamnya akuisisi pengetahuan dan pengalaman, kemamapuan berfikir logis, kreatif dan integrasi intelektual, (3) perkembangan interpersonal, (4) hubungan institusi-institusi sosial, organisasi sosial, dan budaya masyarakat. Oleh karena itulah, Schutz ingin mengembangkan model pembelajaran untuk memenuhi salah satu dari keempat tipe perkembangan tersebut, yaitu perkembangan interpersonal. Tujuannya adalah untuk meningkatkan pemahaman diri dan kesadaran akan perilaku orang lain sehingga dapat membantu siswa mengembangkan perkembangan pribadi dan sosialnya (Uno, 2012, hlm. 21).

\section{Prosedur Pembelajaran}

Kunci utama prosedur pembelajaran model ini didasarkan atas teori humanistik. Teori ini menjelaskan metode untuk meningkatkan kesadaran hubungan antar manusia yang didasarkan atasketerbukaan, kejujuran, kesadaran diri tanggung jawab, perhatian terhadap diri sendiri atau orng lain, dan orientasi pada kondisi saat ini. Model pembelajaran ini terdiri atas dua tahapan. Pertama adalah penyampaian dan penyelesaian tugas. Pada tahapan ini guru memberikan pengarahan tentang tugas yang akan diberikan dan bagaimana melaksanakannya. Tahapan kedua adalah diskusi atau ananlisis tahap pertama. Jadi, intinya siswa diminta melakukan sesuatu, setelah itu mendiskusikannya (refleksi bersama) atas apa yang telah terjadi.

\section{Aplikasi}

Permainan sederhana dapat dilakukan untuk keperluan ini. Model ini juga dapat dilakukan sebagai selingan yang tidak memakan waktu terlalu banyak. Dalam pelaksanaan diskusi, keterbukaan dan kejujuran menjadi sangat penting. Hasil penelitian menunjukkan bahwa model ini dapat meningkatkan perkembangan emosi (Uno, 2012, hlm. 21).

\section{Kemampuan Interpersonal}

Kemampuan interpersonal merupakan salah satu kemampuan atau intelegensi yang dimiliki oleh setiap individu manusia. Howard Gardner menemukan adanya delapan macam intelegensi, diantaranya yaitu, intelegensi linguistik, intelegensi logis matematis, intelegensi visual spasial, intelegensi kinestetis, intelegensi musikal, intelegensi naturalis, intelegensi interpersonal, dan intelegensi intrapersonal (Sugiarto, 2011, hlm. 23).

Dalam Santrock (2009, hlm. 158) dijelaskan bahwa keterampilan interpersonal merupakan kemampuan untuk memahami diri secara efektif berinteraksi dengan orang lain (guru yang berhasil, ahli kesehatan mental). Sedangkan dalam Sugiarto (2011, hlm. 26) dijelaskan bahwa intelegensi interpersonal adalah kemampuan bersosialisasi yang berkembang sejak masa kanak-kanak dan dapat berubah seiring bertambahnya usia. Adapun untuk melihat seseorang memiliki keterampilan interpersonal lebih dominan, dapat dilihat dari ciriciri kelompok berikut:

1. Menyukai pekerjaan yang berhubungan dengan orang lain atau dalam kelompok.

2. Menyenangi permainan yang melibatkan banyak peserta.

3. Pandai berkomunikasi bahkan memanipulasi.

4. Jika mempunyai masalah, mereka senang membicarakannya dengan orang lain.

5. Sering dimintai pendapat karena mereka umumnya mudah bersimpati.

(Sugiarto, 2011, hlm. 26)

Jika mengacu pada teori Gardner, kemampuan interpersonal disebut juga dengan intelegensi interpersonal. Intelegensi sama dengan kemampuan atau keterampilan berdasar pada pengertian yang diungkapkan oleh Santrock (2009, hlm. 151) bahwa intelegensi adalah keterampilan menyelesaikan masalah dan kemampuan untuk beradaptasi dan belajar dari pengalaman kehidupan sehari-hari. 
Kemampuan interpersonal berhubungan erat dengan nilai rasa hormat dan tanggung jawab. Kedua nilai tersebut salah diperlukan untuk pengembangan kemampuan interpersonal. Seperti yang diungkapkan Thomas (2013, hlm. 69) bahwa nilai-nilai rasa hormat dan tanggung jawab merupakan dua sikap moral yang paling utama. Nilai-nilai tersebut sangat diperlukan untuk:

1) Pengembangan jiwa yang sehat.

2) Kepedulian akan hubungan interpersonal.

3) Sebuah masyarakat yang humanis dan demokratis.

4) Dunia yang adil dan damai.

Rasa hormat menunjukkan penghargaan kita terhadap harga diri orang lain ataupun hal lain selain diri kita.Sedangkan tanggung jawab menekankan pada kewajiban positif untuk saling melindungi satu sama lain (Thomas, hlm. 71-72). Oleh karena itu, kemampuan interpersonal atau pun nilai-nilai sikap yang dapat menumbuhkan kemampuan interpersonal harus dilatih sehingga memunculkan kesadaran pada masing-masing individu.

Hughes \& Hughes (2012, hlm. 105) berpendapat bahwa Pengulangan merupakan dasar dari semua pembentukan kebiasaan. Kita bertindak dengan cara yang sama berulang kali sampai perilaku semacam ini menjadi mudah dan tak dapat dilakukan dengan sedikit atau bahkan tanpa sadar. Selain itu, Hughes \& Hughes (2012, hlm. 109) pun menyatakan bahwa kemampuan untuk membentuk kebiasaan adalah syarat yang sangat perlu bagi perkembangan perilaku. Makhluk-makhluk yang berperilaku klise dan tetap sejak lahir tidak membentuk kebiasaan baru; mereka tidak menunjukkan kemampuan menyesuaikan diri dengan keadaan yang baru. Artinya, jika kebiasaan sejak lahir tidak pernah dilatih untuk berubah dan berkembang, maka diaakan memiliki hambatan untuk menyesuaikan dengan keadaan lingkungan. Oleh karena itu, pelatihan kesadaran ternyata sangat diperlukan. Salah satunya adalah untuk menumbuhkan kemampuan interpersonal.

\section{METODE PENELITIAN}

Metode kualitatif digunakan untuk mengidentifikasi kemampuan interpersonal mahasiswa Program Studi Pendidikan Bahasa \& Sastra Indonesia di STKIP Siliwangi menggunakan model pembelajaran Pelatihan Kesadaran (Awarenes Training). Penggunaan metode ini pun berlandaskan pada rumusan masalah, tujuan dan manfaat penelitian.
Metode penelitian kualitatif adalah metode penelitian yang digunakan untuk meneliti pada kondisi obyek yang alamiah. Peran peneliti sebagai instrumen kunci, teknik pengumpulan data dilakukan secara triangulasi (gabungan), analisis data bersifat induktif, dan hasil penelitian kualitatif lebih menekankan makna dari pada generalisasi (Sugiyono, 2014, hlm. 1). Artinya, penelitian kualitatif pada hakekatnya ialah mengamati orang dalam lingkungan hidupnya, berinteraksi dengan mereka, berusaha memahami bahasa dan tafsiran mereka tentang dunia sekitarnya (Nasution dalam Sugiyono, 2014, hlm. 180).

Dalam penelitian ini, objek yang diamati adalah orang yaitu sampel mahasiswa Program Studi Pendidikan Bahasa dan Sastra Indonesia di STKIP Siliwangi Bandung pada semua angkatan. Pengamatan dilakukan saat berlangsung proses pembelajaran di kelas serta hasil jawaban angket yang diisi oleh mahasiswa. Butir-butir soal angket yang diberikan pada mahasiswa merujuk pada indikator kemampuan interpersonal berdasarkan teori yang ada dalam model pembelajaran Pelatihan Kesadaran (Awarenes Training). Data hasil angket diperkuat dengan hasil pengamatan selama proses pembelajaran yang dilakukan oleh dosen dengan tetap beracuan pada indikator yang sama dengan angket. Oleh karena itu, jika dilihat dari proses pengamatan dalam menggumpulkan data, metode penelitian ini menggunakan kualitatif karena dikembalikan pada hakekatnya menurut Nasution.

Data yang diteliti diperoleh dari hasil angket yang diisi dan proses pengamatan terhadap sampel mahasiswa Program Studi Pendidikan Bahasa dan Sastra Indonesia di STKIP Siliwangi Bandung pada semua angkatan. Sumber data tersebut sesuai dengan fokus dan tujuan penelitian. Adapun sumber data untuk mengetahui kemampuan interpersonal mahasiswa adalah mahasiswa angkatan 2013 yang diambil satu kelas A3. Sedangkan teknik pengumpulan datanya adalah dengan penyebaran angket dan pengamatan langsung di kelas saat proses pembelajaran.

Instrumen penelitian yang utama dalam penelitian ini adalah peneliti sendiri dan angket. Namun, ke depannya jika fokus permasalahan sudah semakin jelas, maka akan dikembangkang instrumen lainnya. Instrumen yang dikembangkan diharapkan dapat memperdalam kajian penelitian dan menghasilkan sebuah inovasi pembelajaran. 
Teknik analisis data dilakukan setelah pengumpulan data berupa hasil angket. Miles \& Huberman (dalam Sugiyono, 2014, hlm. 91) mengemukakan bahwa aktivitas dalam analisis data kualitatif dilakukan secara interaktif dan berlangsung secara terus menerus sampai tuntas, sehingga datanya sudah jenuh. Aktivitas dalam analisis data, yaitu data reduction, data display, dan conclusion drawing/verification.

Pengujian keabsahan data hingga akhirnya dapat ditarik kesimpulan penelitian adalah dengan cara:
a. Meningkatkan ketekunan
b. Triangulasi
c. Menggunakan bahan referensi
d. Mengadakan member check

\section{PEMBAHASAN}

\section{A. Gambaran Umum Objek Literatur}

Kemampuan interpersonal Mahasiswa merupakan objek kajian dalam penelitian ini. Perilaku diri sendiri (mahasiswa) dan kesadaran terhadap orang lain ketika melakukan interaksi sosial adalah kemampuan interpersonal yang dimiliki oleh mahasiswa sebagai bekal melakukan proses pembelajaran. Sebagaimana teori Gardner, kemampuan interpersonal disebut juga dengan intelegensi interpersonal. Intelegensi sama dengan kemampuan atau keterampilan berdasar pada pengertian yang diungkapkan oleh Santrock (2009, hlm. 151) bahwa intelegensi adalah keterampilan menyelesaikan masalah dan kemampuan untuk beradaptasi dan belajar dari pengalaman kehidupan sehari-hari.

Sebagai objek kajian, kemampuan interpersonal mahasiswa yang diidentifikasi dan dideskripsikan adalah angket yang telah diberikan kepada mahasiswa STKIP Siliwangi Bandung, khususnya angkatan 2013 kelas A3. Adapun yang menjadi kriteria untuk mengidentifikasi kemampuan interpersonal mahasiswa sebagai objek penelitian adalah berikut :

Tabel 4.1

\section{Kriteria Identifikasi}

\begin{tabular}{|c|l|}
\hline No. & \multicolumn{1}{|c|}{$\begin{array}{c}\text { Pengidentifikasian Kemampuan } \\
\text { Interpersonal }\end{array}$} \\
\hline 1 & $\begin{array}{l}\text { Pekerjaan yang berhubungan dengan } \\
\text { orang lain atau kelompok }\end{array}$ \\
\hline 2 & $\begin{array}{l}\text { Kegiatan yang melibatkan banyak } \\
\text { peserta. }\end{array}$ \\
\hline 3 & Cara berkomunikasi kepada orang lain \\
\hline
\end{tabular}

\begin{tabular}{|c|l|}
\hline No. & \multicolumn{2}{|c|}{$\begin{array}{c}\text { Pengidentifikasian Kemampuan } \\
\text { Interpersonal }\end{array}$} \\
\hline 4 & $\begin{array}{l}\text { Cara mengatasi masalah pribadi dan } \\
\text { kelompok }\end{array}$ \\
\hline 5 & $\begin{array}{l}\text { Keberanian berbicara di tempat } \\
\text { umum/khalayak ramai }\end{array}$ \\
\hline
\end{tabular}

\section{B. Deskripsi Kemampuan Interpersonal Mahasiswa}

Kemampuan awal Interpersonal mahasiswa semester 6 Program Studi Bahasa dan Sastra Indonesia diketahui dari hasil angket pertama yang disebarkan. Data tersebut dianalisis berdasarkan aspek pengidentifikasian kemampuan interpersonal mahasiswa yang terdiri atas enam aspek. Selanjutnya data dideskripsikan berdasarkan aspek kemampuan interpersonal mahasiswa. Data yang dikutip dalam analisis berupa kalimat pertanyaan yang sesuai dengan kriteria pada tiap aspek. Hasil angket yang telah diisi mahasiswa dikelompokkan ke dalam empat kategori yaitu sangat baik, baik, sedang dan kurang berdasarkan ciri-ciri kemampuan interpersonal yang dimiliki oleh seseorang.

\section{Deskripsi Kemampuan Interpersonal Mahasiswa Sebelum Mengikuti Pelatihan Kesadaran (Awarenes Training) dalam Mata Kuliah Inovasi Pembelajaran}

Kemampuan interpersonal mahasiswa berdasarkan kriteria identifikasi kemampuan interpersonal belum memiliki kemampuan interpersonal secara dominan. Hal ini terlihat dari hasil sebaran angket yang diberikan, sebagai berikut.

1. Kriteria identifikasi pada aspek pekerjaan yang berhubungan dengan orang lain atau kelompok, kegiatan yang melibatkan banyak peserta, dan cara berkomunikasi kepada orang lain dengan pertanyaan a) Gaya belajar yang Anda pergunakan selama ini: visual, audio, dan kinestetik memperoleh persentase sebesar visual 15,5\%, 24,2\%, dan 60,6\%. b) Apakah Anda suka mengerjakan tugas/latihan yang berikan oleh guru/dosen secara individu tanpa meminta bantuan teman atau orang sekitar Anda? memperoleh jawaban $Y a$ sebesar 63,6\% sedangkan Tidak sebesar 36,6\%. c) Apakah Anda suka mengerjakan tugas/latihan yang berikan oleh guru/dosen secara bersama-sama (kerja kelompok, diskusi) dengan meminta bantuan teman atau orang sekitar Anda? memperoleh jawaban $Y a$ sebesar $45,4 \%$ dan Tidak 54,5\%. 
2. Kriteria identifikasi pada aspek cara mengatasi masalah pribadi dan kelompok dengan pertanyaan d) Apakah Anda selalu mengerjakan dan mengumpulkan tugas tepat waktu? memperoleh jawaban $Y a$ sebesar $60,6 \%$ dan Tidak 39,3\%. e) Apakah Anda sering mencontek saat mengerjakan tugas/ujian? memperoleh jawaban $Y a$ sebesar $(75,5 \%$ dan Tidak 24,2\%. f) Apakah Anda pernah mencontek saat mengerjakan tugas/ujian? memperoleh jawaban $Y a$ sebesar $87,8 \%$ dan Tidak 12,1\%. g) Apakah Anda tidak pernah mencontek saat mengerjakan tugas/ujian? memperoleh jawaban $Y a$ sebesar $54,5 \%$ dan Tidak 45,4\%. h) Apakah Anda selalu berdoa setiap melakukan sesuatu? memperoleh jawaban $Y a$ sebesar 60,6\% dan Tidak 39,3\%.

3. Kriteria identifikasi pada aspek keberanian berbicara di tempat umum/khalayak ramai dengan pertanyaan i) Apakah Anda senang berdiskusi mengenai suatu hal misalnya, materi pelajaran, tugas, aktivitas, dsb.? memperoleh jawaban $Y a$ sebesar 27,2\% dan Tidak 72,7\%. j) Apakah Anda sering dimintai pendapat oleh teman, guru/dosen, dan orang tua? memperoleh jawaban $Y a$ sebesar 72,7\% dan Tidak 27,2\%. k) Apakah Anda senang tampil di depan umum (menjadi narator, moderator, pembicara, menyampaikan pendapat)? memperoleh jawaban $Y a$ sebesar 45,4\% dan Tidak 54,5\%.

\section{Deskripsi Kemampuan Interpersonal Mahasiswa Sesudah Mengikuti Pelatihan Kesadaran (Awarenes Training) dalam Mata Kuliah Inovasi Pembelajaran}

Kemampuan interpersonal mahasiswa berdasarkan kriteria identifikasi kemampuan interpersonal mahasiswa sudah memiliki kemampuan interpersonal cukup dominan. Hal ini terlihat dari hasil sebaran angket yang diberikan, sebagai berikut.

1. Kriteria identifikasi pada aspek pekerjaan yang berhubungan dengan orang lain atau kelompok, kegiatan yang melibatkan banyak peserta, dan cara berkomunikasi kepada orang lain dengan pertanyaan a) Gaya belajar yang Anda pergunakan selama ini: visual, audio, dan kinestetik memperoleh persentase sebesar visual $15,5 \%, 24,2 \%$, dan 60,6\%. b) Apakah Anda suka mengerjakan tugas/latihan yang berikan oleh guru/dosen secara individu tanpa meminta bantuan teman atau orang sekitar Anda? memperoleh jawaban $\mathrm{Ya}$ sebesar 54,5\% sedangkan Tidak sebesar 45,4\%. c) Apakah Anda suka mengerjakan tugas/latihan yang berikan oleh guru/dosen secara bersama-sama (kerja kelompok, diskusi) dengan meminta bantuan teman atau orang sekitar Anda? memperoleh jawaban $Y a$ sebesar $87,8 \%$ dan Tidak $12,1 \%$.

2. Kriteria identifikasi pada aspek cara mengatasi masalah pribadi dan kelompok dengan pertanyaan d) Apakah Anda selalu mengerjakan dan mengumpulkan tugas tepat waktu? memperoleh jawaban $Y a$ sebesar $87,8 \%$ dan Tidak 12,1\%. e) Apakah Anda sering mencontek saat mengerjakan tugas/ujian? memperoleh jawaban $Y a$ sebesar $(90,9 \%$ dan Tidak 9,09\%. g) Apakah Anda pernah mencontek saat mengerjakan tugas/ujian? memperoleh jawaban $\mathrm{Ya}$ sebesar $72,7 \%$ dan Tidak 27,7\%. f) Apakah Anda tidak pernah mencontek saat mengerjakan tugas/ujian? memperoleh jawaban $Y a$ sebesar 36,3\% dan Tidak 63,6\%. h) Apakah Anda selalu berdoa setiap melakukan sesuatu? memperoleh jawaban $Y a$ sebesar 60,6\% dan Tidak 39,3\%.

3. Kriteria identifikasi pada aspek keberanian berbicara di tempat umum/khalayak ramai dengan pertanyaan i) Apakah Anda senang berdiskusi mengenai suatu hal misalnya, materi pelajaran, tugas, aktivitas, dsb.? memperoleh jawaban $Y a$ sebesar 87,8\% dan Tidak 12,2\%.j) Apakah Anda sering dimintai pendapat oleh teman, guru/dosen, dan orang tua? memperoleh jawaban $Y a$ sebesar 84,8\% dan Tidak 15,1\%. k) Apakah Anda senang tampil di depan umum (menjadi narator, moderator, pembicara, menyampaikan pendapat)? memperoleh jawaban $Y a$ sebesar 57,5\% dan Tidak 42,4\%.

\section{Analisis Data Hasil Pelatihan Model Pembelajaran Pelatihan Kesadaran (Awarenes Training) dalam Mata Kuliah Inovasi Pembelajaran}

Analisis hasil sebaran angket dapat diperoleh dari hasil perhitungan nilai sebaran angket sebelum mengikuti pelatihan dan sesudah mengikuti pelatihan. Perolehan hasil sebaran sebelum dan sesudah mengikuti pelatihan tersebut dilakuakan dalam dua tahap. Tahap pertama, yaitu penyebaran angket yang dilakukan di awal sebelum pelatihan dilakukan. Tahap kedua, yaitu penyebaran angket yang dilakukan di akhir. Sampel yang digunakan yaitu mahasiswa angkatan 2013 kelas A3 STKIP Siliwangi Bandung. 


\section{Analisis Data Sebelum dan Sesudah Model Pembelajaran Pelatihan Kesadaran (Awarenes Training) dalam Mata Kuliah Inovasi Pembelajaran}

Berdasarkan sebaran angket yang diperoleh di atas, maka hal pertama yang dilakukan peneliti untuk melihat perbedaan hasil sebaran dan perkembangan kemampuan belajar siswa, harus dilakukan perhitungan selisih sesudah dan sebelum pelatihan kesadaran (Arwarnes Training) dalam mata kuliah inovasi pembelajaran. Perbedaan dan perkembangan kemampuan interpersonal mahasiswa diketahui melalui pertanyaanpertanyaan yang diajukan dalam angket yang kemudian pertanyaan tersebut dikelompokan berdasarkan kriteria identifikasi kemampuan interpersonal mahasiswa.

Dilihat dari hasil perhitungan sebaran angket sebelum dan sesudah melakukan pelatihan kemampuan interpersonal mahasiswa dalam mata kuliah inovasi pembelajaran diketahui selisih ratarata antara sebaran sebelum dan sesudah sebagai berikut.

a. Kriteria identifikasi pada aspek pekerjaan yang berhubungan dengan orang lain atau kelompok, kegiatan yang melibatkan banyak peserta, dan cara berkomunikasi kepada orang lain.

$$
\begin{aligned}
\text { Selisih Jawaban } \mathbf{Y a} \\
\begin{aligned}
\text { Selisih mean } & =\mathbf{M y}-\mathbf{M x} \\
& =113-112 \\
& =1
\end{aligned}
\end{aligned}
$$

Selisih Jawaban Tidak

$$
\begin{aligned}
\text { Selisih mean } & =\mathbf{M y}-\mathbf{M x} \\
& =19-39 \\
& =-20
\end{aligned}
$$

Berdasarkan perhitungan selisih dari jawaban sebaran angket terlihat kemampuan interpersonal mahasiswa mengalami peningkatan dalam kategori cukup. Artinya mahasiswa sudah dapat berkerjasama, berhubungan, dan berkomunikasi dengan baik dengan orang lain.

b. Kriteria identifikasi pada aspek cara mengatasi masalah pribadi dan kelompok Selisih Jawaban $\mathbf{Y a}$

Selisih mean $=\mathbf{M y}-\mathbf{M x}$

$$
=113-112
$$

$$
=1
$$

Selisih Jawaban Tidak

$$
\begin{aligned}
\text { Selisih mean } & =\mathbf{M y}-\mathbf{M x} \\
& =52-53 \\
& =-1
\end{aligned}
$$

Berdasarkan perhitungan selisih dari jawaban sebaran angket terlihat kemampuan interpersonal mahasiswa mengalami peningkatan walaupun peningkatan yang terjadi sangat sedikit tetapi tetap dalam kategori cukup. Artinya siswa sudah memiliki kemampuan untuk mengatasi masalah pribadi dan kelompok dengan memerhatikan lingkungan sosialnya.

c. Kriteria identifikasi pada aspek keberanian berbicara di tempat umum/khalayak ramai.

\section{Selisih Jawaban $\mathbf{Y a}$}

Selisih mean $=\mathbf{M y}-\mathbf{M x}$

$$
\begin{aligned}
& =76-48 \\
& =28
\end{aligned}
$$

Selisih Jawaban Tidak

$$
\begin{aligned}
\text { Selisih mean } & =\mathbf{M y}-\mathbf{M x} \\
& =23-51 \\
& =-28
\end{aligned}
$$

Berdasarkan perhitungan selisih dari jawaban sebaran angket terlihat ke-mampuan interpersonal mahasiswa mengalami peningkatan dalam kategori cukup. Artinya mahasiswa memiliki kemampuan dan keberanian untuk berbicara di depan umum.

\section{Pembahasan Hasil Penelitian}

Model pembelajaran pelatihan kesadaran merupakan suatu model pembelajaran yang ditujukan untuk meningkatkan kesadaran manusia. Pelatihan kesadaran (Awarenes Training) merupakan salah satu cara untuk meningkatkan dan mengasah kemampuan interpersonal seseorang. Setiap individu manusia memiliki kemampuan interpersonal. Kemampuan interpersonal individu manusia satu dan lainnya berbeda-beda ada yang tidak dominan, dominan, dan sangat dominan. Santrock (2009, hlm. 158) mengungkap-kan bahwa keterampilan interpersonal merupakan kemampuan untuk memahami diri secara efektif berinteraksi dengan orang lain (guru yang berhasil, ahli kesehatan mental).

Adapun untuk melihat seseorang memiliki keterampilan interpersonal lebih dominan menurut Sugiarto (2011, hlm. 26) dapat dilihat dari ciri-ciri kelompok berikut.

1. Menyukai pekerjaan yang berhubungan dengan orang lain atau dalam kelompok.

2. Menyenangi permainan yang melibatkan banyak peserta.

3. Pandai berkomunikasi bahkan memanipulasi.

4. Jika mempunyai masalah, mereka senang membicarakannya dengan orang lain.

5. Sering dimintai pendapat karena mereka umumnya mudah bersimpati. 
Berdasarkan kelima ciri tersebut dan melihat hasil sebaran angket yang telah dilakukan maka dapat diketahui mahasiswa memiliki kemampuan interpersonal yang cukup. Seperti diketahui bahwa kemampuan interpersonal disebut juga dengan intelegensi yaitu keterampilan menyelesaikan masalah dan kemampuan untuk beradaptasi dan belajar dari pengalaman kehidupan sehari-hari. Artinya kemampuan interpersonal mahasiswa dapat terus meningkat melalui pelatihan secara berkesinambungan.

\section{SIMPULAN}

Hasil penelitian dan pembahasan pada bab sebelumnya menunjukan bahwa secara umum dapat disimpulkan evaluasi pembelajaran melalui penulisan jurnal reflektif berbasis penilaian diri dalam pembelajaran bahasa dapat meningkatkan kualitas pembelajaran mahasiswa STKIP Siliwangi Bandung. Jurnal reflektif merupakan hasil catatan dan analisis yang harus memiliki siklus reflektif sebagai bahan pertimbangan atau pengambilan keputusan (tindak lanjut) untuk perbaikan kegiatan pembelajaran selanjutnya. Secara khusus beberapa hal yang dapat disimpulkan sesuai dengan rumusan penelitian sebagai berikut.

1. Berdasarkan hasil sebaran angket yang dilakukan sebelum dan sesudah pelatihan kesadaran diri (Awarenes Training) kemampuan interpersonal yang dimiliki oleh mahasiswa mulai ada. Tanggung jawab mahasiswa dalam menyelesaikan tugas yang diberikan oleh dosen dapat diselesaikan dengan mengoptimalkan kemampuan interpersonalnya dengan baik dengan memanfaatkan aspek menyelesaikan pekerjaan yang berhubungan dengan orang lain atau dalam kelompok.

2. Kemampuan interpersonal mahasiswa dalam memahami diri sendiri terhadap tugas yang diberikan dosen sudah mulai nampak hal ini terlihat dari interaksi sosial mahasiswa ketika menyelesaikan tugas yang diberikan sudah dapat memilih mana yang harus diselesaikan secara individu, bersama-sama, dan harus meminta tolong kepada teman (lingkungan sekitar) atau tidak.

Kesadaran perilaku diri sendiri (mahasiswa) dan kesadaran terhadap orang lain ketika melakukan interaksi sosial dapat dilatih tentunya dengan pelatihan yang tepat. Kemampuan interpersonal mahasiswa STKIP Siliwangi Angkatan 2013 kelas A3 mengalami perubahan (peningkatan) hal ini terlihat dari hasil sebaran angket yang dilakukan. Pertanyaan-pertanyaan dalam angket untuk mengidentifikasi kemampuan interpersonal yang dimiliki oleh mahasiswa. Diketahui berdasarkan kriteria (aspek) identifikasi kemampuan interpersonal mahasiswa: a) kriteria identifikasi pada aspek pekerjaan yang berhubungan dengan orang lain atau kelompok, kegiatan yang melibatkan banyak peserta, dan cara berkomunikasi kepada orang lain. berada dalam kategori cukup. Artinya siswa sudah dapat berkerjasama, berhubungan, dan berkomunikasi dengan baik dengan orang lain. Hal ini berdasarkan perhitungan sebelum dan sesudah pelatihan kesadaran diri (Awarnes Training) yaitu selisih $\mathrm{Ya}$ sebesar 1 dan selisih Tidak sebesar 20. b) kriteria identifikasi pada aspek cara mengatasi masalah pribadi dan kelompok Selisih Jawaban $Y a 1$ dan selisih Jawaban Tidak -1. Artinya terlihat kemampuan interpersonal mahasiswa mengalami peningkatan walaupun peningakatan yang terjadi sangat sedikit tetapi tetap dalam kategori cukup. c) kriteria identifikasi pada aspek keberanian berbicara di tempat umum/khalayak ramai. Selisih Jawaban $Y a 28$ sedangkan Selisih Jawaban Tidak 28. Kemampuan interpersonal mahasiswa mengalami peningkatan dalam kategori cukup. Artinya mahasiswa memiliki kemampuan dan keberanian untuk berbicara di depan umum.

\section{DAFTAR PUSTAKA}

Djiwandono, Sri Esti W. (2009). Psikologi Pendidikan. Jakarta: Grasindo.

Fluerentin, E. (2012). Latihan Kesadaran Diri (Self Awareness) dan Kaitannya dengan Pembunuhan Karakter. e-jurnal. Diunduh pada 30 Januari 2016.

Hughes, A.G. \& E.H. Hughes. (2012). Learning \& teaching pengantar psikologi pembelajaran modern. Penerjemah SPA teamwork. Yogyakarta. Bandung: NUANSA.

Lickona, T. (2013). Educating for character: mendidik untuk membentuk karakter bagaimana sekolah dapat mengajarkan sikap hormat dan tanggung jawab penerjemah: juma abdu wamaungo. Jakarta: Bumi Aksara.

Marlina, N., dkk. (2014). Meningkatkan hasil belajar pada mata pelajaran pendidikan kewarganegaraan melalui model pembelajaran pelatihan kesadaran (awareness training) di kelas VII Sekolah Menengah Pertama Negeri 2 Atinggola. E-jurnal. 3 (2). Diunduh pada 30 Januari 2016. 
Nana, S. S. (2011). Landasan psikologi proses pendidikan. Bandung: PT rosdakarya offset.

Sugiarto, I. (2011). Mengoptimalkan daya kerja otak dengan berpikir holistik \& kreatif. Jakarta: Gramedia.

Sugiyono. (2014). Memahami penelitian kualitatif. Bandung: Alfabeta.

Santrock, John W. (2009). Psikologi pendidikan. Jakarta: Salemba Humanika.

Sahmini, M. \& Yeni R. (2015). Pengembangan alat evaluasi menulis karya ilmiah dengan pendekatan proses. Cimahi: STKIP Siliwangi.

Uno, Hamzah B. (2012). Model pembelajaran: menciptakan proses belajar mengajar yang kreatif dan efektif. Jakarta: Bumi Aksara 